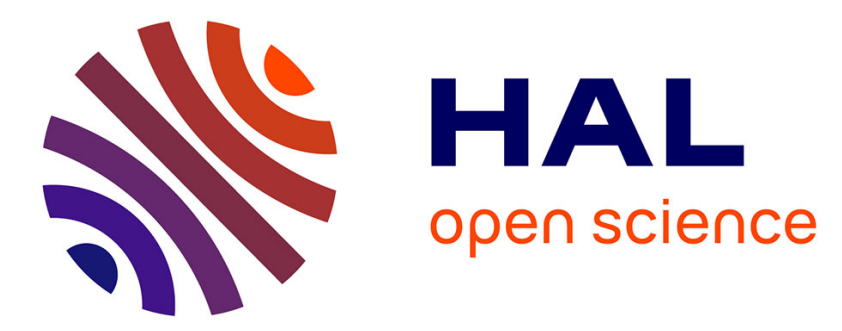

\title{
Grain legume seed filling in relation to nitrogen acquisition: A review and prospects with particular reference to pea
}

Christophe Salon, Nathalie G. Munier-Jolain, Gérard Duc, Anne-Sophie Voisin, David Grandgirard, Annabelle Larmure, Robert Emery, Bertrand Ney

\section{To cite this version:}

Christophe Salon, Nathalie G. Munier-Jolain, Gérard Duc, Anne-Sophie Voisin, David Grandgirard, et al.. Grain legume seed filling in relation to nitrogen acquisition: A review and prospects with particular reference to pea. Agronomie, 2001, 21 (6-7), pp.539-552. 10.1051/agro:2001143 . hal-00886153

\section{HAL Id: hal-00886153 https://hal.science/hal-00886153}

Submitted on 1 Jan 2001

HAL is a multi-disciplinary open access archive for the deposit and dissemination of scientific research documents, whether they are published or not. The documents may come from teaching and research institutions in France or abroad, or from public or private research centers.
L'archive ouverte pluridisciplinaire HAL, est destinée au dépôt et à la diffusion de documents scientifiques de niveau recherche, publiés ou non, émanant des établissements d'enseignement et de recherche français ou étrangers, des laboratoires publics ou privés. 


\title{
Grain legume seed filling in relation to nitrogen acquisition: A review and prospects with particular reference to pea
}

\author{
Christophe SALON ${ }^{\mathrm{a} *}$, Nathalie G. Munier-Jolain ${ }^{\mathrm{a}}$, Gérard Duc ${ }^{\mathrm{b}}$, Anne-Sophie VoIsIN ${ }^{\mathrm{a}}$, \\ David GRANDGIRARD ${ }^{\mathrm{a}}$, Annabelle LARMURE ${ }^{\mathrm{c}}$, Robert J.N. EMERY ${ }^{\mathrm{d}}$, Bertrand NEY ${ }^{\mathrm{e}}$ \\ a INRA, Unité de Malherbologie et Agronomie, BP 86510, 21065 Dijon Cedex, France \\ b INRA, Unité de Génétique et Amélioration des Plantes, BP 86510, 21065 Dijon Cedex, France \\ c ENESAD, Département Sciences et Techniques Agronomiques, BP 87999, 21079 Dijon Cedex, France \\ d Trent University, Department of Biology, Peterborough, K9J 7B8 Ontario, Canada \\ ${ }^{\mathrm{e}}$ INRA-INAPG, 78850 Thiverval-Grignon, France
}

(Received 30 October 2000; revised 13 March 2001; accepted 31 August 2001)

\begin{abstract}
Seed filling depends not only on the instantaneous supply of C and N, but also on their remobilisation from vegetative organs. C supply during seed filling depends mostly on current photosynthesis, but $\mathrm{N}$ assimilation and $\mathrm{N}_{2}$ fixation decline during seed filling, with newly acquired $\mathrm{N}$ generally insufficient for the high seed demand. As seeds are strong sinks for mobilised nutrients, seed growth becomes metabolically closely associated with $\mathrm{N}$ remobilisation. $\mathrm{N}$ remobilisation from vegetative tissues to filling seeds interacts with photosynthesis since it induces senescence, which reduces the seed filling period. Hence improved grain legume seed filling requires either reduced dependency on $\mathrm{N}$ remobilisation or enhanced $\mathrm{N}$ supply. This latter might be obtained either by prolonging the activity of symbiotic fixation, increasing the potential for root assimilation of soil mineral $\mathrm{N}$ or optimising complementarity between both $\mathrm{N}$ acquisition pathways, which does not affect the quantity and the quality of the seed reserves.
\end{abstract}

symbiotic fixation / $\mathrm{N}$ assimilation / remobilisation / seed filling / senescence

Résumé - Remplissage des graines de légumineuses en relation avec la nutrition azotée : revue et prospective avec en référence le pois protéagineux. Le remplissage des graines dépend non seulement de l'offre instantanée en $\mathrm{C}$ et en $\mathrm{N}$ mais aussi des remobilisations à partir des organes végétatifs. Durant le remplissage des graines l'offre en $\mathrm{C}$ repose principalement sur la photosynthèse, l'assimilation d'azote minéral du sol et la fixation symbiotique diminuant durant cette période. L'azote exogène récemment accumulé étant alors insuffisant pour satisfaire les besoins élevés des graines, leur vitesse de croissance devient alors associée métaboliquement aux remobilisations d'azote. Ces remobilisations d'azote interagissent avec la photosynthèse, induisent la sénescence, ce qui réduit la durée de remplissage des graines. L'amélioration du remplissage des graines de légumineuses repose, soit sur une dépendance réduite envers les remobilisations d' $\mathrm{N}$, soit sur une fourniture d'azote exogène accrue. Cette dernière peut être obtenue, soit en prolongeant l'activité de la fixation symbiotique, soit en augmentant le potentiel pour l'assimilation racinaire de l'azote minéral du sol ou encore en optimisant la complémentarité entre les deux modes de prélèvement d'azote, ce qui n'affecte pas la quantité ou la qualité des réserves des graines.

fixation symbiotique / assimilation d'azote / remobilisation / remplissage des graines / sénescence

Communicated by Jean-Jacques Drevon (Montpellier, France)

* Correspondence and reprints

salon@dijon.inra.fr 


\section{INTRODUCTION}

The mechanisms involved in determining yield and quality of leguminous crops require further study for improving crop management or increasing and stabilising yield components. For pea, nitrogen $(\mathrm{N})$ content and amount of reserve proteins remain highly variable with all aspects of $\mathrm{N}$ flux from $\mathrm{N}$ acquisition to its partitioning within seeds needing detailed evaluation.

In order to analyse how $\mathrm{N}$ accumulation occurs in legume seeds we need to consider (i) $\mathrm{C}$ and $\mathrm{N}$ acquisition by the crop, including root assimilation of soil mineral $\mathrm{N}$ and symbiotic nitrogen $\left(\mathrm{N}_{2}\right)$ fixation, (ii) $\mathrm{N}$ partitioning among the organs of the plant and its effect on potentially re-mobilisable $\mathrm{N}$ for seed fill, the rate of $\mathrm{N}$ transfer and the potential for overall seed $\mathrm{N}$, (iii) the influence of environmental factors on $\mathrm{N}_{2}$ fixation and mineral $\mathrm{N}$ assimilation, and their interactions at the end of the seed filling period.

In this paper we briefly review, using earlier published results, the current knowledge concerning $\mathrm{N}$ flux at the level of the plant and crop, considering both the characterisation of $\mathrm{C}$ and $\mathrm{N}$ supply during seed filling and the relationship between the rate of $\mathrm{N}$ accumulation in seeds and $\mathrm{N}$ availability. Using data from a recently conducted field experiment, we suggest some prospects that might be useful in order to enhance grain legume seed filling, in relation to $\mathrm{N}$ nutrition, of leguminous crops, especially pea.

\section{MATERIALS AND METHODS}

\subsection{Site}

The field experiment was conducted in 1997 at the INRA experimental field station $30 \mathrm{~km}$ south of Dijon (France) on a clayey calcic brown soil (clayey eutric Cambisol). At sowing, the soil contained about $30 \mathrm{~kg} / \mathrm{ha}$ $\mathrm{NO}_{3}{ }^{-}+\mathrm{NH}_{4}{ }^{+}$. Adequate $\mathrm{P}, \mathrm{K}$ and $\mathrm{Mg}$ fertilisation was performed $\left(\mathrm{P}_{2} \mathrm{O}_{5}, \mathrm{~K}_{2} \mathrm{O}\right.$ and $\mathrm{MgO}$ supplied as 104, 104 and $49 \mathrm{~kg} / \mathrm{ha}$ resp.) during the autumn that preceded the experiment. Irrigation was provided on two occasions to avoid drought stress. Rhizobium leguminosarum was naturally present in the soil, so no inoculation was needed.

\subsection{Treatment and experimental design}

In order to vary the mode of $\mathrm{N}$ accumulation by the plants, nodulated peas (cv. Frisson) either relying exclusively on symbiotic fixation (treatment Frisson-0) or provided with a dose of $250 \mathrm{~kg} \cdot \mathrm{ha}^{-1}$ mineral $\mathrm{N}$ (treatment Frisson-250) were used. A nitrate-tolerant hypernodulat- ing mutant of Frisson (P90), which carries a mutation at the level of the sym 29 gene [58] allowed us to test for an enhanced potential of symbiotic fixation through an increased number of established nodules. A non-nodulating mutant of Frisson (P2) supplied with similar amounts of $\mathrm{N}$ fertiliser [16] was used as the reference plant for the measure of the contribution of symbiotic $\mathrm{N}$ fixation to overall $\mathrm{N}$ acquisition by the crops $\left({ }^{15} \mathrm{~N}\right.$ isotope dilution technique). Peas were sown in March 15th 1997, at a density of 80 per $\mathrm{m}^{2}$, in a randomised split-plot design with crops as main plots, $\mathrm{N}$ treatments as sub-plots and with four replications. Each plot had 6 rows of plants spaced $0.2 \mathrm{~m}$ apart. Border plots of peas sown at the same density surrounded the experimental plots.

The ${ }^{15} \mathrm{~N}$ isotope dilution technique with a low-level${ }^{15} \mathrm{~N}$ enrichment of the soil was used to estimate symbiotic $\mathrm{N}$ fixation [16]. Soil was enriched with $5 \mathrm{~kg} \cdot \mathrm{ha}^{-1}$ of ${ }^{15} \mathrm{~N}$ labelled ammonium nitrate dissolved in water and sprayed at a rate of $300 \mathrm{~L} \cdot \mathrm{ha}^{-1}[16]$.

\subsection{Sampling procedures and measurements}

The aerial parts of the plants were harvested at 2 day intervals, with the inner 4 rows being collected in $1 \mathrm{~m}$ lengths (which represented $0.8 \mathrm{~m}^{2}$ plots). Dry matter was determined after oven drying at $80{ }^{\circ} \mathrm{C}$ for 48 hours. Nitrogen content was determined by the Dumas procedure using a CHN analyser (Carlo Erba); isotopic analysis was performed with a single inlet double collector mass spectrometer (Fisons instruments) operating in line with a CHN analyser (Carlo Erba).

\subsection{Calculation of symbiotic nitrogen fixation}

The percentage of $\mathrm{N}$ derived from symbiotic fixation was calculated using as control plants non-nodulating mutants of Frisson (P2).

The percentage of $\mathrm{N}$ that was derived from fixation (\% Ndfa) was calculated using the isotope dilution principle $[1,2,40,41]$.

$$
\begin{gathered}
\% \mathrm{Ndfa}=100 \cdot\left(\delta^{15} \mathrm{~N} \text { legume }-\delta^{15} \mathrm{~N} \text { reference plant }\right) / \\
\left(\varepsilon f i x-\delta^{15} \mathrm{~N} \text { reference plant }\right)
\end{gathered}
$$

where $\varepsilon f i x$ ( -1 for pea) is the isotopic enrichment factor associated with $\mathrm{N}_{2}$ fixation processes [40, 41].

\subsection{Calculations and statistical analysis}

Analysis of variance was performed with the GLM procedure of SAS and means where classified using the 
least significant difference test (LSD) at the 0.05 probability level [61].

\section{RESULTS AND DISCUSSION}

\subsection{Accumulation of carbon and nitrogen by filling seeds}

\subsubsection{Characterisation of carbon and $N$ supply during seed filling}

\subsubsection{Carbon supply to filling seeds}

During seed filling, carbon transfer from vegetative organs to pods and seeds principally involves recently photosynthesised carbon [82]. Respiration of older, fully expanded leaves increases strongly during senescence and some structural carbon may be mobilised towards the meristems for use in biosynthesis. However this represents a negligible amount leaving mainly the current photosynthesis to feed growing seeds [82].

\subsubsection{Nitrogen supply}

Nitrogen accumulation by the seeds during seed filling depends upon the external $\mathrm{N}$ supply ( $\mathrm{N}$ retrieval from the soil and symbiotic fixation of atmospheric $\mathrm{N}_{2}$ ) which generally cannot sustain the high $\mathrm{N}$ demand of developing seeds $[31,35,51]$. Hence, seed growth throughout the plant involves $\mathrm{N}$ remobilisation $[51,68]$. All organs undergo $\mathrm{N}$ remobilisation but the efficiency with which it can be transferred to growing seeds and the rate of remobilisation may vary according to the organ and the regime of $\mathrm{N}$ nutrition.

\subsection{Nitrogen remobilisation from vegetative organs}

Compartment: Seeds may be filled, according to the node position, either by $\mathrm{N}$ coming from exogenous $\mathrm{N}$ and N-remobilisation from vegetative parts or simply by the remobilised $\mathrm{N}$ : this latter being most of the time the main $\mathrm{N}$ source for upper nodes' seeds [5]. Leaves and stems contribute the most to $\mathrm{N}$ supply of the seeds [53] while $\mathrm{N}$ from pods $[51,53]$ constitutes a temporary $\mathrm{N}$ reserve for seed filling [50]. Roots are probably much less involved [51, 53] as they represent a low proportion of the total plant biomass and they have to be integrally maintained throughout the growth cycle for mechanical support and nutrient uptake. Moreover there may be some rhizodeposition of $\mathrm{N}$ from roots to the soil instead of its re-export through xylem.

Quantity of N-potential remobilisation: Remobilised $\mathrm{N}$ from the vegetative organs to seeds comes principally from $\mathrm{N}$ which has already been accumulated during the vegetative period [83]. Part of this $\mathrm{N}$ accumulates in structural compounds of leaves, which is not very accessible for remobilisation [11]. The low $\mathrm{N}$ content of the vegetative organs that is observed when premature end of seed filling occurs demonstrates that remaining $\mathrm{N}$ which has not been remobilised is effectively associated with structures [42]. Non-remobilisable N can be considered as a constant proportion of the vegetative biomass [42]. Therefore, the quantity of remobilisable $\mathrm{N}$ of vegetative tissues is calculated as the difference between the total $\mathrm{N}$ and the non-remobilisable $\mathrm{N}$ determined at harvest $[17,42]$. In the case of pea, vegetative growth has ceased by the start of seed filling and the amount of nonremobilisable $\mathrm{N}$ can be considered constant. In addition, pea leaves are not abscised [3] and the calculations are then simplified as compared with soybean where the fall of leaves can constitute a substantial loss of $\mathrm{N}$.

Protein sources and mechanisms of remobilisation: Most of the redistributed $\mathrm{N}$ comes from enzymatic degradation of proteins and metabolic inter-conversion of the products of this catabolism. Rubisco represents 30 to $60 \%$ of soluble proteins: hence it is a high source of potential available $\mathrm{N}$ (besides its role in $\mathrm{C}$ acquisition). Vegetative soluble proteins, which are stored in leaves, stems or roots, may also represent a substantial supply of $\mathrm{N}$. Proteolysis plays a crucial role in the process of $\mathrm{N}$ redistribution in the plant. Although the sites of action of proteases are well known, both the specificity of these enzymes for a particular substrate and the catabolic pathways involved (in particular for Rubisco) are unknown $[9,27]$. Remobilisable $\mathrm{N}$ does not seem to be available immediately after all the seeds have begun to fill and there is a lag observed before the maximum $\mathrm{N}$ remobilisation rate occurs [34]. This timing may correspond to the increase of proteolytic enzymes' activity in the vegetative plant tissues during reproductive development.

Prospects for a better knowledge of $N$ remobilisation: There is now a need for extensive studies on $\mathrm{N}$ remobilisation that take into account environmental variables (i.e. temperature, soil water status...) in order to precisely determine the extent and the sequence of $\mathrm{N}$ remobilisation from the various organs. More than environmental parameters the genetic variability associated with $\mathrm{N}$ remobilisation $[5,64]$ also has to be explored in order to highlight the underlying physiological mechanisms; such a variability may be associated with architectural characteristics.

In the field $\mathrm{N}$ remobilisation patterns have been derived from biomass and percent $\mathrm{N}$ variations of the plant organs. However, using such data, precise N remobilisation patterns to filling seed cannot be obtained as the plant organs continue to invest exogenous $\mathrm{N}$ which cannot be measured in the $\mathrm{N}$ budgets. To study $\mathrm{N}$ 
remobilisation precisely, the use of ${ }^{15} \mathrm{~N}$-labelled fertiliser allows discrimination between exogenous $\mathrm{N}$ supply and $\mathrm{N}$ retrieved from the vegetative parts. Studies involving ${ }^{15} \mathrm{~N}$ have been conducted on pea genotypes after labelling during the vegetative stage and they demonstrate that the various patterns of remobilisation indeed arose from differential $\mathrm{N}$ investment according to the plant nodes [5]. The labour-intensive use of several labelling experiments over the growth cycle gives a precise quantification and a better understanding of the various N sources during seed filling [21].

Nowadays the physiological mechanisms involved in $\mathrm{N}$ remobilisation processes [9] and genetic variability remain under study and should receive much more attention.

\subsection{External $\mathrm{N}$ supply during seed filling}

A pea crop can continue to accumulate $\mathrm{N}$ late into the growth cycle, although the amount of $\mathrm{N}$ being incorporated varies greatly according to environmental conditions [7, 31]. For most leguminous plants, symbiotic fixation decreases sharply after flowering [28, 35, 69, 74]. Although less sensitive to environmental factors than symbiotic fixation, mineral $\mathrm{N}$ assimilation also declines during seed filling. However under optimum, wellwatered conditions symbiotic fixation can nonetheless continue to supply $\mathrm{N}$ during seed filling $[8,74]$. Roots can also retrieve a substantial amount of soil mineral $\mathrm{N}$ if it is available.

Estimation of the amount of external $N$ supply for filling seeds: During the growth of a crop its $\mathrm{N}$ content diminishes as $\mathrm{N}$ is being progressively diluted in the biomass [36]. The variation in $\mathrm{N}$ concentration as a function of the dry matter accumulation has led to the concept of the $\mathrm{N}$ critical curve [36], which is defined as the minimum $\mathrm{N}$ concentration in dry matter required for the maximal growth of the crop. It is determined specifically for different crops.

For pea, a $\mathrm{N}$ critical curve has been established [47] and the $\mathrm{N}$ concentration of the whole plant appears to be constant after seeds start to fill (Fig. 1), hence N accumulation thereafter becomes proportional to dry matter accumulation.

As such, provided the $\mathrm{N}$ concentration of the shoots is measured at the start of seed filling, the measurement of dry matter accumulation during seed filling allows determination of the external $\mathrm{N}$ supply to the crop. Although quite accurate, this relationship is rather empirical and knowledge of the mechanisms of $\mathrm{N}$ accumulation needs to be extended.

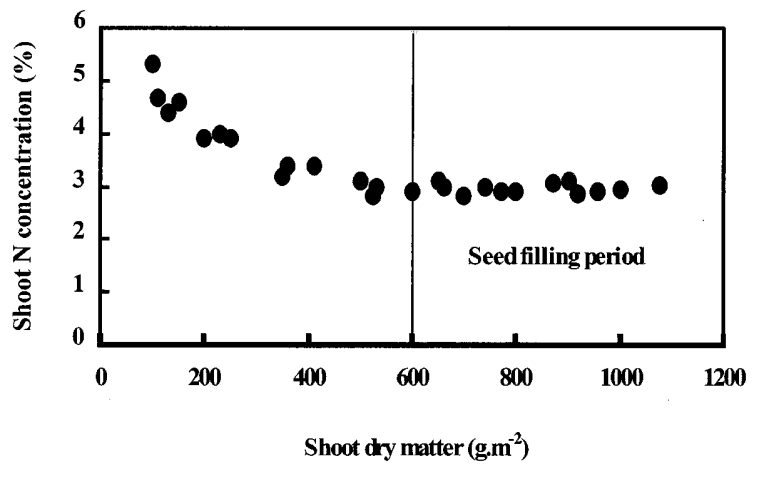

Figure 1. N dilution curve established for pea plants (from [47]).

\subsubsection{Relationship between the rate of $N$ accumulation in seeds and $N$ availability}

During seed filling, $\mathrm{N}$ being accumulated is devoted predominantly to seeds, although there are temporary transfers to the vegetative organs [50]. During this period symbiotically fixed $\mathrm{N}$ seems to be preferentially transferred to growing seeds while mineral $\mathrm{N}$ is equally distributed between seeds and mature vegetative organs [80]. Fixed N could be reserved in a particular pool of storage compounds [71] before feeding the developing seeds.

$\mathrm{N}$ accumulation rate in filling seeds is slightly variable throughout the seed filling period [38] and may decline, for example, in response to deficient $\mathrm{N}$ nutrition [29]. There seems to be no variable compartmentation of $\mathrm{N}$ within the plant and during some periods all seeds have the same rate of $\mathrm{N}$ accumulation [38].

A relationship between the rate of $\mathrm{N}$ accumulation by seeds and $\mathrm{N}$ availability (remobilisable and externally supplied) has been recently established [39]. This relationship (Fig. 2) shows that the rate of $\mathrm{N}$ accumulation by filling seeds increases with $\mathrm{N}$ availability up to a maximum value. $\mathrm{N}$ content and acquisition are however variable between genotypes during seed filling and this results in a variable rate of $\mathrm{N}$ accumulation by seeds.

Using the relation linking the rate of $\mathrm{N}$ accumulation by seeds and $\mathrm{N}$ availability (Fig. 2), a model simulating $\mathrm{N}$ partitioning to filling seeds has been constructed in order to predict the $\mathrm{N}$ content of seeds from the different nodes at harvest and simulate the change in $\mathrm{N}$ content of the vegetative organs from the start of seed filling to harvest [37]. The end of seed filling is often due to 


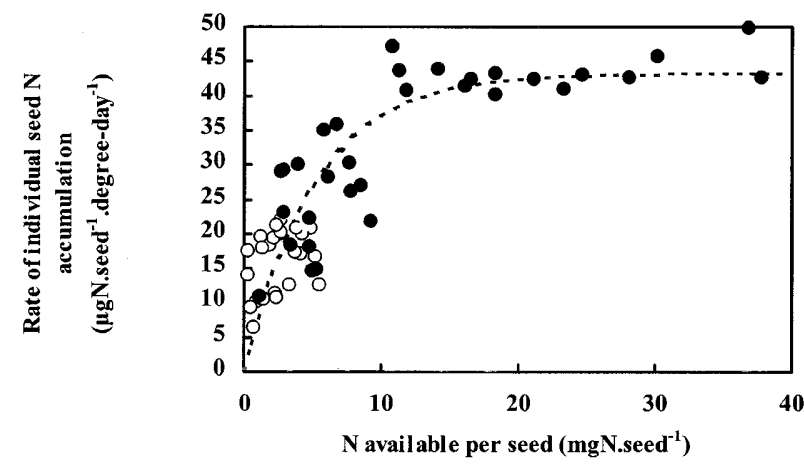

Figure 2. Relationship between $\mathrm{N}$ accumulation in pea seeds and $\mathrm{N}$ availability for two genotypes: Solara, $\bigcirc$ Frisson (from [38]).

vegetative organs reaching the non-remobilisable $\mathrm{N}$ concentration [42].

The validation of the model shows that there is an overestimation of the quantity of $\mathrm{N}$ potentially available at the onset of grain filling [37] which can result from inaccuracies in methods that determine the exogenous $\mathrm{N}$ supply using dry matter accumulation.

\subsection{Prospects for an enhanced grain legume seed filling}

As a consequence of the seed $\mathrm{N}$ requirement, reallocation of $\mathrm{N}$ from the vegetative tissues to seeds during seed filling interacts with the $\mathrm{CO}_{2}$ assimilation rate. The destruction of the photosynthetic machinery and reexport of the protein content of leaves to growing seeds leads to senescence. As foliar senescence determines the duration of canopy light interception, this determines the end of $\mathrm{C}$ accumulation by the seeds and hence seed size.

Increasing the duration of the seed filling period and the amount of $\mathrm{N}$ accumulated by seeds may be obtained by delaying foliar senescence. This relies on (i) reducing or optimising $\mathrm{N}$ remobilisation during seed filling (see above), (ii) prolonging symbiotic fixation activity during seed growth, (iii) optimising the complementarity between both modes of $\mathrm{N}$ acquisition throughout the growth cycle and particularly during seed filling. This is especially true when competition for assimilates and environmental conditions often depress symbiotic fixation and when root exploration of nutrients is insufficient to compensate for the lack of atmospheric $\mathrm{N}$ retrieval.

\subsubsection{Symbiotic fixation activity during seed filling}

Although the maximum symbiotic fixation rate has been proposed to occur at the beginning of seed filling [77] there is a high variability concerning the fixation pattern in peas and fixation maximum can range from the beginning of flowering up to seed filling [4]. The maximum symbiotic fixation rate differs according to the varieties but the duration during which the crop fixes $\mathrm{N}$ symbiotically may be rather stable for a given sowing date [12]: delaying the sowing date reduced the duration of the $\mathrm{N}_{2}$ fixation period while a delayed flowering did not affect $\mathrm{N}_{2}$ fixation which continued during seed filling [12].

Modulation of nodule activity during seed filling: The sink strength of the vegetative organs is strongly reduced when the young reproductive organs are developing and filling seeds constitute an additional sink which has priority for assimilates [33]. The strong demand of seeds for $\mathrm{C}$ and $\mathrm{N}$ reduces the assimilate supply to the vegetative organs $[31,68]$, and induces $\mathrm{N}$ remobilisation from the vegetative organs which provokes release of N-soluble compounds in the pholem sap, eventually inhibiting nodule activity $[26,45]$. The decline in nitrogenase activity thereafter induces modification of the ratio of amino compounds available to the tricarboxylic cycle which in turn may reduce the glycolytic flow in alfalfa nodules [13]. Hence the tremendous competition for assimilates during seed filling, by way of a $\mathrm{N}$-feedback, severely decreases nodule activity.

Carbon requirements for symbiotic fixation: Symbiotic fixation needs $\mathrm{C}$ for nodule function (morphogenesis and maintenance of the structures, atmospheric $\mathrm{N}$ reduction) and the transfer of reduced $\mathrm{N}$ as amino compounds towards the shoots [85]. The energy required for these processes comes from current photosynthesis in the form of sucrose $[34,51]$. The amount of photosynthetates transferred towards nodules varies according to the species, age and phenology. It represents between 8 and 23\% of net photosynthesis [6]. Part of the transferred carbon (about $10 \%$ in soybean) is trapped in the nodule biomass and about $20 \%$ is incorporated in the carbon skeletons exported via the xylem. The remaining large amount of carbon is oxidised (and results in respiratory $\mathrm{CO}_{2}$ evolution) to supply energy and reduced components which are necessary for nitrogenase activity, $\mathrm{N}$ assimilation and maintenance of the nodules [6].

Increasing the potential for symbiotic fixation: In order to compensate for a loss of symbiotic fixation activity during seed filling, either the amount of nodules per plant might be enhanced or the duration of symbiotic fixation activity might be prolonged. Dual inoculation involving beneficial free-living soil bacteria, referred to 
as plant growth promoting rhizobacteria, may exert a beneficial effect upon plant growth. Among them, phosphate-solubilising bacteria (PSB) and Azospirillum species have proven to be useful as biofertilisers for agriculture improvement [20].

Dual inoculation may imply different mechanisms such as (i) solubilisation of minerals such as phosphorus (using PSB) which would positively affect symbiotic fixation activity, or (ii) causing root physiological changes (using Azospirillum) leading to enhanced mineral and water uptake by inoculated plants [48]. Phosphate-solubilising bacteria increased both $\mathrm{P}$ uptake by the plant and crop yield [57] while inoculating legumes with both rhizobia and azospirilla induced an early nodulation, increased the number of nodules, produced higher $\mathrm{N}_{2}$ fixation rates, and resulted in a general improvement of root development [22, 53].

Pea nodules have an indeterminate structure [46] and the host's control of the nodule number, via systemic autoregulatory signals, has been confirmed with supernodulating mutants which often share nitrate tolerance: such mutants have a much higher nodule number which is controlled by the shoot genotype $[17,58]$ except for the nod 3 pea mutant, whose nodule number appears to be regulated by the roots [30]. Increased nodulation events can occur on both primary and secondary roots but in any case they are located on the older root parts which shows that inhibition of nodulation mostly concerns the young root parts [59]. Genetic variability concerning nodule distribution on soybean roots has been reported [10]. Although, in pea, nodulation events increase linearly with time [59] to date there is no report of the relative contribution of primary and secondary root nodulation to the overall $\mathrm{N}$ budget of the crop.

Carbon partitioning as affected by an enhanced potential for symbiotic fixation: In order to analyse the effect of an enhanced potential of symbiotic fixation (through an increase in nodule number) on dry matter accumulation and carbon partitioning, a field experiment was conducted at the INRA experimental station at Dijon (France): both nodulated peas (cv. Frisson), relying exclusively on symbiotic fixation, and a nitrate-tolerant hypernodulating mutant of Frisson (P90) were sown. Symbiotic fixation contribution to total $\mathrm{N}$ accumulation was measured using the ${ }^{15} \mathrm{~N}$ isotope dilution method [16, 54].

As expected, the hypernodulating nitrate-tolerant mutant of Frisson P90 obtained about $82 \%$ of $\mathrm{N}$ via symbiotic fixation throughout its growth cycle. In contrast, at the beginning of the vegetative growth, Frisson relied on mineral $\mathrm{N}$ assimilation but thereafter symbiotic fixation contribution increased, eventually reaching about $90 \%$ of total $\mathrm{N}$ accumulation during seed filling (Tab. I). As a whole, the total amount of $\mathrm{N}$ accumulated was much lower for P90 but its shoot $\mathrm{N}$ concentration was similar to Frisson throughout the growth cycle and it was mainly dry matter accumulation which was affected (Fig. 3). Although during the early vegetative phase similar dry matter accumulation was observed for Frisson and its hypernodulating counterpart P-90, large differences were subsequently observed, especially after the end of the flowering period (Fig. 3). During seed filling, while Frisson continued to accumulate large amounts of dry matter, mostly invested in its seeds, P-90 dry matter accumulation reached a plateau at about half of the amount of biomass harvested for Frisson at physiological maturity (Fig. 3). Similar results have been obtained in other pea mutants $[30,58]$ and where root dry matter accumulation was reduced. Aerial dry matter was also reduced on hypernodulating soybean mutants [79].

The suggested high carbon cost of symbiotic fixation (including nodule organogenesis and functioning of the symbiosis) was presumably responsible for the large carbon consumption which reduced shoot dry matter accumulation. Thus the synthesis of the associated structure (nodules) or their sustained activity appeared to be detrimental to the carbon budget at the level of the aerial biomass and seed yield. Pea and other legumes subjected to increasing $\mathrm{CO}_{2}$ atmospheric concentrations have much more nodules [44] and a strong correlation has been found between the presence/absence of nodules on a root segment and the root elongation rate, during the time separating infection and appearance of nodules [73] which suggests that assimilate partitioning and/or availability might be linked to nodule morphogenesis.

Table I. Nitrogen accumulation and contribution of dinitrogen fixation to overall $\mathrm{N}$ acquisition for cv. Frisson and P90 (nitrate tolerant hypernodulating mutant of Frisson). Values are expressed as mean \pm SD.

\begin{tabular}{lccc}
\hline Genotype & $\begin{array}{c}\text { Total N accumulation } \\
\left(\mathrm{mg} \cdot \text { plant }^{-1}\right)\end{array}$ & $\begin{array}{c}\text { Symbiotically fixed } \mathrm{N} \\
\left(\mathrm{mg} \cdot \mathrm{plant}^{-1}\right)\end{array}$ & $\begin{array}{c}\text { Contribution of } \mathrm{N}_{2} \text { fixation to } \\
\text { overall N acquisition }(\%)\end{array}$ \\
\hline Frisson & $349 \pm 36$ & $311 \pm 32$ & $89 \pm 3$ \\
P90 & $153 \pm 3$ & $125 \pm 2$ & $81 \pm 6$ \\
\hline
\end{tabular}




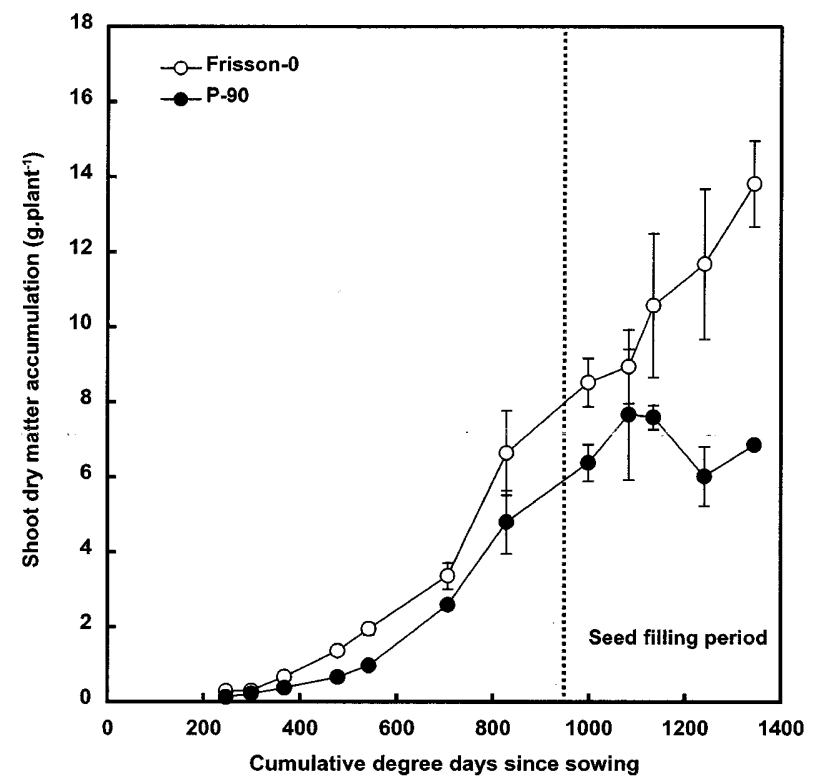

Figure 3. Dry matter accumulation for pea, cv. Frisson and P90 (nitrate tolerant hypernodulating mutant of Frisson). Values are mean of four replicates \pm SD.

Hence, carbon partitioning at the level of the whole plant is greatly modified by the enhanced potential for symbiotic fixation and this is presumably related to the costs associated with root and nodule morphogenesis and activity. Labelling experiments under controlled environmental conditions $\left({ }^{13} \mathrm{CO}_{2}\right.$ enrichment of the shoots and ${ }^{15} \mathrm{~N}_{2}$ enrichment of the root atmosphere) are helpful in order to relate $\mathrm{N}$ fixation activity to carbon assimilation and allocation to different organs. During such labelling experiments a large proportion of the carbon currently assimilated by photosynthesis was observed to be respired by the nodulated roots (Voisin, unpublished results): while at the vegetative stage respiration of nodulated roots represented about $40 \%$ of the carbon photosynthetically assimilated (as measured using ${ }^{13} \mathrm{CO}_{2}$ ), it decreased to around $20 \%$ at the seed filling period (data not shown). This demonstrates the high respiratory cost associated with morphogenesis (especially during the vegetative period), and maintenance and activity of roots and nodules thereafter. Further analysis of nodulated root respiration curves will permit calculation of the different carbon costs associated with symbiotic fixation for pea. These costs include nodule synthesis and maintenance, and energy requirements directly incurred in the reaction of $\mathrm{N}_{2}$ reduction $[81,84,85]$.

Increasing the potential for symbiotic fixation throughout the growth cycle, either by the amount of structures involved in that process (the nodules) or by the activity of $\mathrm{N}$ reduction, assimilation and export by the nodules, results in a higher consumption of assimilates which affects the shoot to root ratio: eventually dry matter accumulation and yield decrease which is against the primary objective of enhanced $\mathrm{N}$ nutrition.

Analysing carbon partitioning in relation to root morphogenesis should give insight regarding the functioning of the root system. Optimising carbon partitioning between root and nodule morphogenesis, in view of their different activities of $\mathrm{N}$ retrieval, appears to be an alternative to increasing external $\mathrm{N}$ supply during seed filling.

\subsubsection{Reaching an efficient complementarity between assimilation and fixation}

Mineral $\mathrm{N}$ availability in the soil inhibits nodule formation and nitrogenase activity, but a mixed $\mathrm{N}$ nutrition regime produces a similar total $\mathrm{N}$ accumulation. Increasing the $\mathrm{N}$ availability in soil by adding fertilisers leads to the progressive replacement of symbiotic $\mathrm{N}$ fixation by root assimilation of soil mineral $\mathrm{N}$ [60], demonstrating the complementary relationship between these modes.

\subsubsection{Root uptake of mineral $N$ and symbiotic fixation under optimal conditions}

In a field experiment under non-water-limiting conditions (which avoid any water stress), nodulated peas (cv. Frisson) relying exclusively on symbiotic fixation (Frisson-0) or provided (Frisson-250) with a dose of mineral $\mathrm{N}\left(250 \mathrm{~kg} \cdot \mathrm{ha}^{-1}\right)$ were sown in order to vary the mode of $\mathrm{N}$ accumulation by plants. Numerous harvests of aerial dry matter, whose $\mathrm{N}$ content was determined, were carried out throughout the growth cycle, which provided us with a dynamic picture of $\mathrm{N}$ acquisition by the crop as a function of time N (Fig. 4). Throughout the growth cycle peas relying exclusively on symbiotic fixation for $\mathrm{N}$ nutrition (Frisson-0) accumulated dry matter with a $\mathrm{N}$ content similar to the mineral $\mathrm{N}$ treated Frisson (Frisson-250; Fig. 4). However dry matter accumulation was significantly lower for Frisson-0 as compared with Frisson-250 before seed filling (Fig. 5). The addition of $250 \mathrm{~kg} \cdot \mathrm{ha}^{-1} \mathrm{~N}$ at sowing favoured the vegetative growth of pea but thereafter Frisson- 0 accumulated relatively more $\mathrm{N}$ than Frisson-250 and at physiological maturity $\mathrm{N}$ contents of the crops were similar (Fig. 5).

Hence under adequately watered conditions both treatments continued to accumulate $\mathrm{N}$ during seed filling and until maturity: the amount of $\mathrm{N}$ retrieved during this period represented for Frisson-250 and Frisson-0 about 


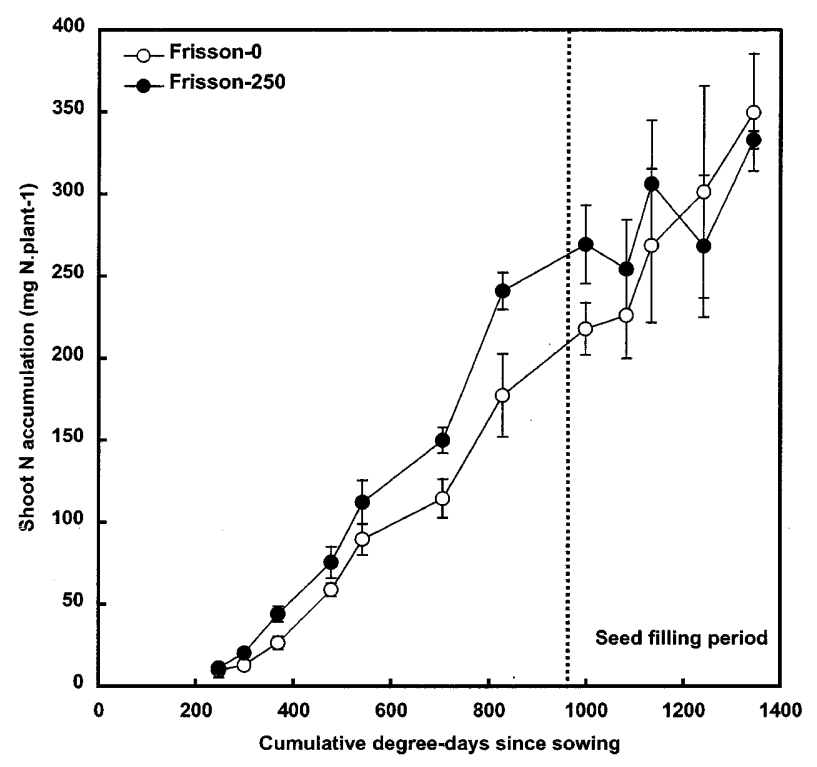

Figure 4. Nitrogen accumulation for pea, cv. Frisson (Frisson0 ) and Frisson treated with $250 \mathrm{~kg} \cdot \mathrm{ha}^{-1}$ mineral N (Frisson250). Values are mean of four replicates \pm SD.

20 and $40 \%$ resp. of the overall $\mathrm{N}$ acquisition during the growth cycle (Fig. 4).

The percentage of $\mathrm{N}$ derived from symbiotic fixation was measured dynamically as a function of phenology using the ${ }^{15} \mathrm{~N}$ isotope dilution method [54, 62] and, as control plants, non-nodulating mutants of Frisson supplied with similar amounts of $\mathrm{N}$ fertiliser [60].

For peas relying essentially on seed reserves and symbiotic fixation for $\mathrm{N}$ acquisition (Frisson-0), the symbiotic fixation contribution increased progressively eventually reaching about $90 \%$ of overall $\mathrm{N}$ accumulation during seed filling (Fig. 6). Root assimilation of soil mineral N by Frisson-0 remained low during the growth cycle (Fig. 6), representing about $40 \mathrm{~kg} \mathrm{~N} \cdot \mathrm{ha}^{-1}$, a value close to the amount of mineral $\mathrm{N}$ measured at sowing in the soil ploughed layer, not taking into account $\mathrm{N}$ which could have come from mineralisation of soil organic matter. During seed filling, $\mathrm{N}$ fixation continued for Frisson- 0 at a rate similar to that observed previously during the growth cycle (about $0.3 \mathrm{mg} \mathrm{N} \cdot$ plant $^{-1}$.degreeday ${ }^{-1}$; Fig. 6).

On the contrary, the treatment that received mineral $\mathrm{N}$ (Frisson-250) relied mostly on root assimilation for its $\mathrm{N}$ uptake throughout the growth cycle (Fig. 6). Dinitrogen fixation was low but increased noticeably at the end of flowering (around 700 degree-days since sowing),

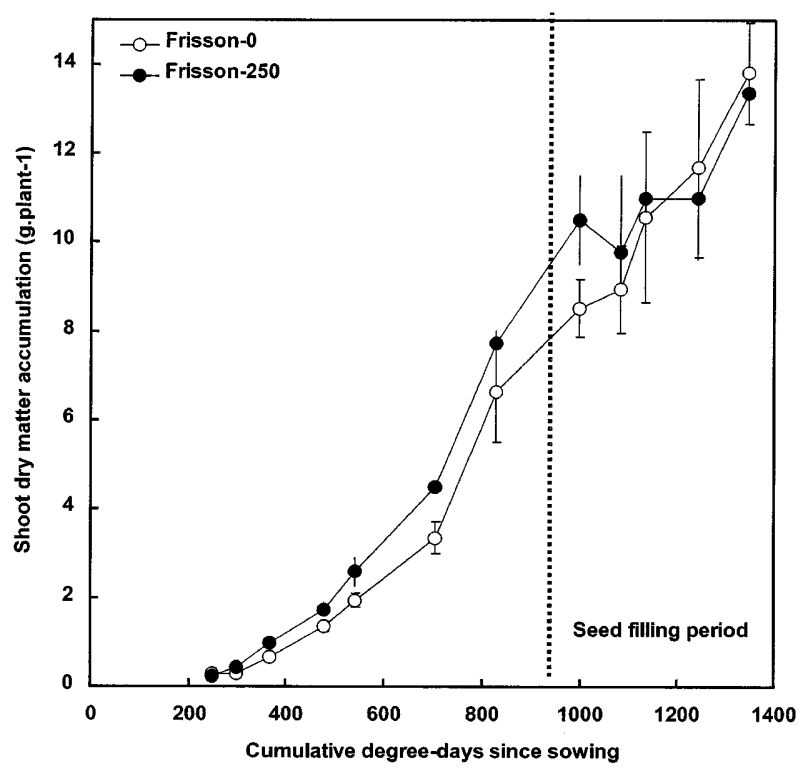

Figure 5. Dry matter accumulation for pea, cv. Frisson (Frisson-0) and Frisson treated with $250 \mathrm{~kg} \cdot \mathrm{ha}^{-1}$ mineral N (Frisson-250). Values are mean of four replicates \pm SD.

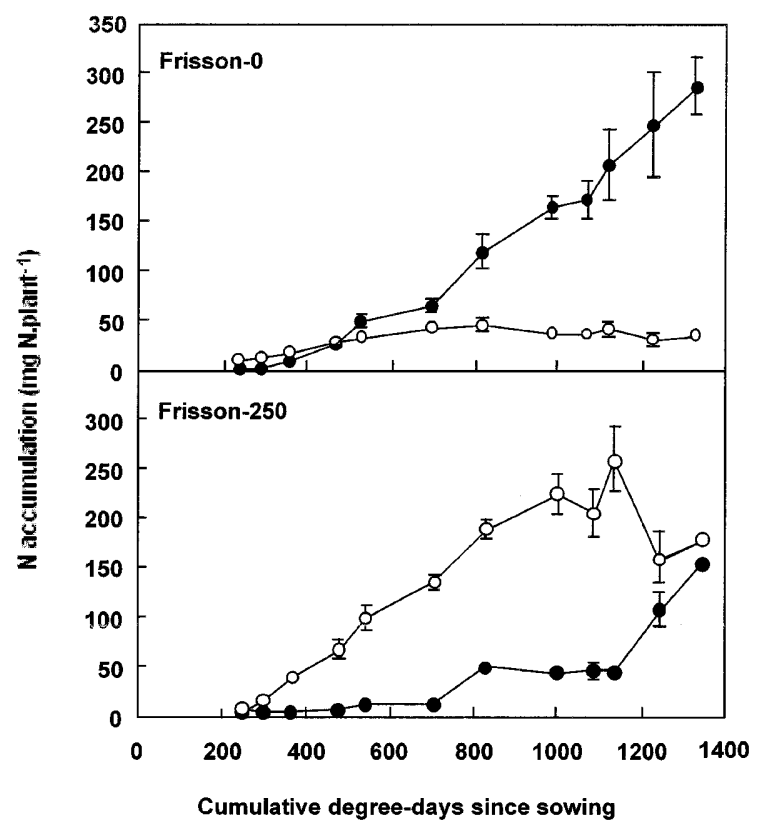

Figure 6. Contribution of symbiotic fixation and root assimilation to overall $\mathrm{N}$ accumulation for pea, cv. Frisson (Frisson-0) and Frisson treated with $250 \mathrm{~kg} \cdot \mathrm{ha}^{-1}$ mineral N (Frisson-250): $\mathrm{N}$ fixed, $\bigcirc \mathrm{N}$ assimilated. Values are mean of four replicates \pm SD. 
stopped until mid-seed filling (i.e. until 1150 degreedays since sowing) and therafter appeared to be enhanced during seed filling. However, during this period $\mathrm{N}$ accumulated into the plant through root assimilation decreased slightly (Fig. 6). An erroneous quantification of the contribution of symbiotic fixation activity for the two late harvests may have been instrumental in this apparent decrease. The ${ }^{15} \mathrm{~N}$ isotope dilution technique needs the accurate choice of a non-fixing reference plant (in this study a non-nodulating mutant of Frisson, P2), which is supposed to provide realistic estimates of the ${ }^{15} \mathrm{~N}$ abundance resulting from mineral $\mathrm{N}$ uptake by the fixing plant. The main hypothesis when using the ${ }^{15} \mathrm{~N}$ isotope dilution technique is that similar spatial and temporal $\mathrm{N}$ pools are acquired by the non-fixing and legume crops. A prerequisite is that root explorations and mineral $\mathrm{N}$ retrieval activities should be similar for the crops [63] which may not have been the case in our study, especially at the end of the growth cycle.

\subsubsection{Nitrogen nutrition during seed filling under stress conditions}

Under optimal conditions, root assimilation can compensate for a decreased symbiotic fixation activity (Fig. 6). Under cropping situations in Mediterranean environments, water stress [24, 65], $\mathrm{pH}$ and salinity [70, 86] or phosphorus limitations [15] usually greatly reduce symbiotic fixation, leaving root assimilation of mineral $\mathrm{N}$ as the only remaining exogenous supply of $\mathrm{N}$ for seed filling. Either the shallow root system of pea [72] may be improved genetically or $\mathrm{N}$-fertiliser judiciously supplied to the crop, considering its amount, form and period of the growth cycle during which it will be applied [31].

\subsection{Genetic variability associated with nodulated root morphogenesis}

Increasing root morphogenesis might be obtained genetically: large roots, deeper roots [23] or more fibrous roots would allow an efficient mineral $\mathrm{N}$ retrieval together with an increased number of nodulation events [52]. It seems that root growth can continue late during the growth cycle and even up to physiological maturity [3] but otherwise, genotypes could be selected according to their root decay timing in order to prolong as much as possible the nutrient and mineral supply to the crop. It might be postulated that delaying the nodulation of firstformed nodules would allow, through a reduction of $\mathrm{C}$ investment toward the benefit of root morphogenesis, a better root system establishment during early growth of the crop while allowing nodulation on deeper secondary roots could influence symbiotic response during drought stresses as deeper nodules would survive better in the case of water shortage [10].

\subsection{Root architecture under various $\mathrm{N}$ nutrition} regimes

Root and nodule morphogenesis and the resulting activities of $\mathrm{N}$ retrieval (mineral $\mathrm{N}$ from the soil and atmospheric dinitrogen) seems to be under the control of a complex signalling system involving regulation both locally, by soil factors, and systemically, through $\mathrm{N}$ feedback mechanisms, in order to adjust the root and nodule development and activities to the nutritional needs of the plants [26]. In particular it is of paramount importance to spatially integrate the mineral $\mathrm{N}$ availability in order to study both the negative local effect of $\mathrm{NO}_{3}{ }^{-}$on morphogenesis and its systemic effect on $\mathrm{N}$ uptake activity.

Although small incorporation of $\mathrm{N}$ at sowing can sustain growth until nodules are formed and may stimulate early vegetative dry matter accumulation, seed yield, dry matter accumulation or $\mathrm{N}$ content are usually not improved [31]. Starter N is not needed when efficient strains are in the soil [50]. Placement of $\mathrm{N}$ at sowing should be deep in order to preclude the inhibition of nodule morphogenesis $[31,76]$.

Increasing the supply of combined $\mathrm{N}$ in the soil during reproductive development may increase the seed yield and $\mathrm{N}$ content without affecting $\mathrm{N}_{2}$ fixation [31]. When supplied after flowering, $\mathrm{N}$-fertiliser usually decreases symbiotic fixation by about 10 to $20 \%$ which is not detrimental to the overall $\mathrm{N}$ acquisition by the crop [31]. Methodologically, attempts to increase exogenous $\mathrm{N}$ supply by foliar $\mathrm{N}$ fertilisation have been made [19] but leaf burning may then occur [78].

The later $\mathrm{N}$ is supplied during reproductive development the better the $\mathrm{N}$ retrieval by the plant and transfer to the seeds appears to be $[31,55]$. For an efficient $\mathrm{N}$ retrieval activity of the root system, soil water content is crucial, as such water content of the different layers of the soils has to be considered together with mineral $\mathrm{N}$ availability.

In a recent field experiment conducted with pea (cv. Baccara) symbiotic fixation was inhibited using various levels of $\mathrm{N}$-fertiliser. Symbiotic $\mathrm{N}$ fixation contributed from $80 \%\left(0 \mathrm{~N}\right.$ treatment supplied with $0 \mathrm{~kg} \cdot \mathrm{ha}^{-1}$ mineral N) to $35 \%\left(200 \mathrm{~N}\right.$ treatment supplied with $200 \mathrm{~kg} \cdot \mathrm{ha}^{-1}$ mineral $\mathrm{N}$ ) of overall $\mathrm{N}$ acquisition (unpublished data). The mode of $\mathrm{N}$ nutrition had no significant effect on shoot development, including phenology and yield, hence plants relying on different $\mathrm{N}$ nutrition regimes developed similar shoot systems in terms of total biomass and seed yield (C and N). Carbon allocation to roots should not differ with the fertiliser $\mathrm{N}$ application and because it has long been suggested that symbiotic fixation has a higher carbon cost than mineral $\mathrm{N}$ 
assimilation (see above) the $\mathrm{N}$ nutrition regime was therefore suspected to influence mainly below-ground parts of the plant. Accordingly, soil blocks including the root system of the plants were excavated to determine root biomass along the soil layers throughout the growth cycle.

Except for the beginning of the growth period, root biomass was always significantly more (about 50\% larger) both in the 0-20 (Fig. 7; from reference [76]) and 20-40 cm (data not shown) soil layers for plants that received $200 \mathrm{~kg} \cdot \mathrm{ha}^{-1}$ mineral $\mathrm{N}$ fertiliser at sowing. Hence, root morphogenesis was enhanced by the presence of mineral $\mathrm{N}$ in the soil. Presumably additional carbon was made available for root growth from lower respiratory losses associated with symbiotic fixation inhibition.

Besides root biomass, rooting depth and root repartition also affect water and nutrient uptake by nodulated roots. Vertical root exploration, within the soil layers, was analysed (Fig. 8) by counting the number of roots along soil profiles, accessed by digging a trench adjacent to the rows. Maximum rooting depth was similar at midflowering between $\mathrm{N}$ treatments and averaged $65 \mathrm{~cm}$. No further increase in rooting depth was observed afterwards by the authors. The profiles showed that the number of roots was largely increased by $\mathrm{N}$ availability (Fig. 8) which also allowed roots to grow faster and earlier in the cycle (data not shown).

These results suggest that, at low mineral $\mathrm{N}$ availability, the cost of symbiotic fixation establishment and functioning might reduce root morphogenesis while, at high mineral $\mathrm{N}$ availability, symbiotic fixation inhibition results in a greater amount of carbon potentially available for root exploration. The latter aspect is a prerequisite for an efficient $\mathrm{N}$ and water regime at the end of the cycle under stressful or limiting conditions.

\subsubsection{Relationship between nitrate availability and symbiotic fixation activity}

Besides the resulting effects of nitrate availability on root morphogenesis, the mechanisms of nitrate inhibition on nodule morphogenesis and activity have been widely investigated [14, 18, 26, 45, 49, 66]. Strong clues have been gained suggesting that the regulation by nitrate of nodule activity could involve a "N-signal" in phloem sap $[26,45,49,67]$. However there has never been any attempt to quantitatively relate symbiotic fixation activity to mineral $\mathrm{N}$ availability in the soil.

In the previous field experiment, the change of mineral $\mathrm{N}$ availability in the soil was measured regularly during the growth cycle. A relationship was established between soil $\mathrm{N}$ availability and percentage of inhibition

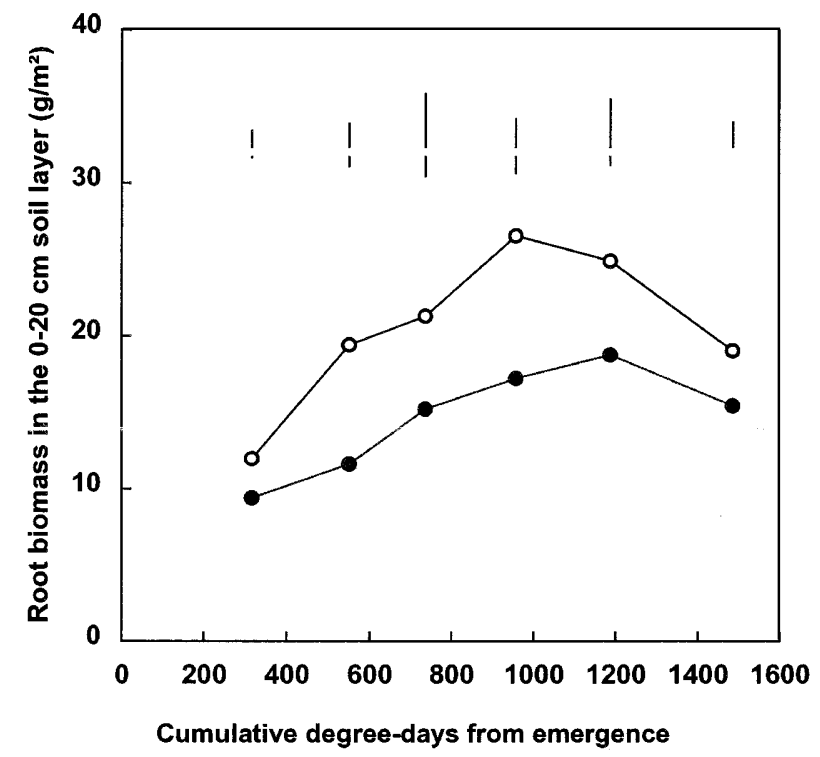

Figure 7. Root dry matter recovered during a growth cycle for pea in the $0-20 \mathrm{~cm}$ soil layer, cv. Frisson (closed symbols) and Frisson treated with $200 \mathrm{~kg} \cdot \mathrm{ha}^{-1}$ mineral N (open symbols). Each point is the mean value of four replicates and vertical bars represent LSD $(p<0.05)$ (from [76]).

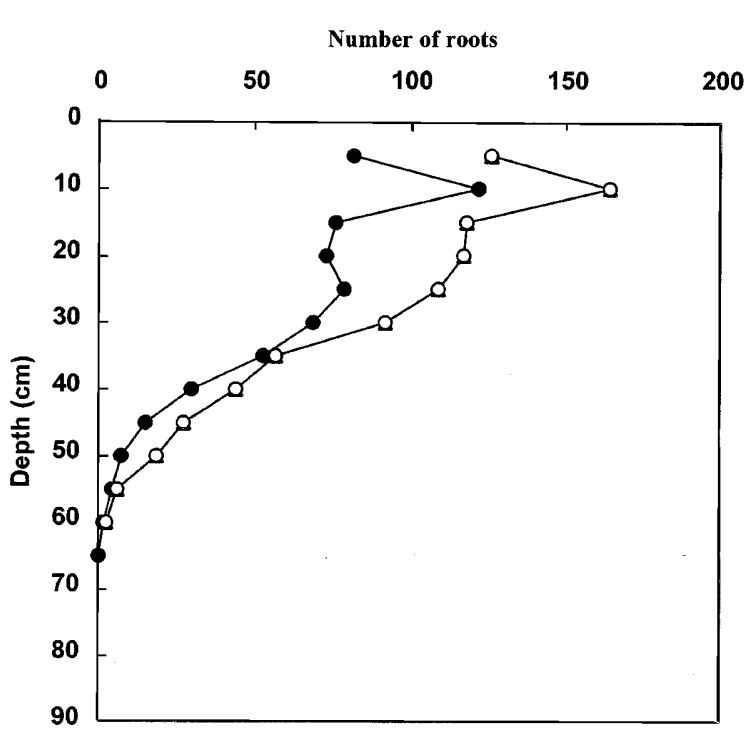

Figure 8. Repartition of the number of roots counted within each $5 \mathrm{~cm}$ soil layer with depth at mid-flowering as affected by mineral $\mathrm{N}$ availability in the soil $(0 \mathrm{~N}(\mathbf{O}) 200 \mathrm{~N}(\bigcirc))$. Each point is the mean value of four replicates (Voisin et al., unpublished). 
of fixation (Fig. 9) [75, 76]. Increasing levels of mineral $\mathrm{N}$ in the soil produced a gradual inhibition of symbiotic fixation which was absolute above $3 \mathrm{~mol} \cdot \mathrm{m}^{-3} \mathrm{~N}$. This relationship was valid regardless of either growth stage or treatment, suggesting that mineral $\mathrm{N}$ availability strongly and precisely limits symbiotic fixation. Furthermore, it reveals there is a consistent threshold mineral $\mathrm{N}$ level that determines when symbiotic fixation will completely cease. This relationship holds late, even during the seed filling stages of the growth cycle under well-watered conditions, but the situation might be quite variable under more stressful conditions.

\subsection{Consequences of the complementarity between fixation and assimilation on grain legume seed filling}

If the accumulation of $\mathrm{N}$ by the crop during seed filling is enhanced, either by prolonged symbiotic fixation or by a better complementarity between assimilation and fixation what would happen with respect to the amount and the content of the seed reserves?

Although the level of $\mathrm{N}$ nutrition modifies the $\mathrm{N}$ concentration of the seeds as previously shown (Fig. 2), for any given level of $\mathrm{N}$ nutrition, the mode of $\mathrm{N}$ acquisition by the crop does not influence the nature of the seed proteins or the $\mathrm{N}$ content of seeds [43].

\section{CONCLUSION}

Additional work is needed concerning $\mathrm{N}$ acquisition during seed filling. It is crucial to consider the complementarity between both modes of $\mathrm{N}$ acquisition and the detrimental effect of their decreased activity on either the amount of $\mathrm{N}$ devoted to seeds or the extent of remobilisation which ultimately leads to the end of seed filling. Several gaps have already been identified.

Nitrogen remobilisation, which depends upon the activity of $\mathrm{N}$ retrieval by roots and nodules, affects carbon acquisition by the crop and may modulate the end of seed filling. Additional work is necessary to elucidate the sequence of $\mathrm{N}$ remobilisation and the amount being solicited as a function of both time and phenology. Genetic variability, which might be associated with architectural characteristics, has to be explored further in order to find the molecular basis of differential plant responses to $\mathrm{N}$ remobilisation.

Research concerning each mode of $\mathrm{N}$ acquisition and the effect of environmental factors is critical. Probably the way to optimise the complementarity between both modes of $\mathrm{N}$ acquisition is by analysing the mechanisms governing root architecture in relation to carbon parti-

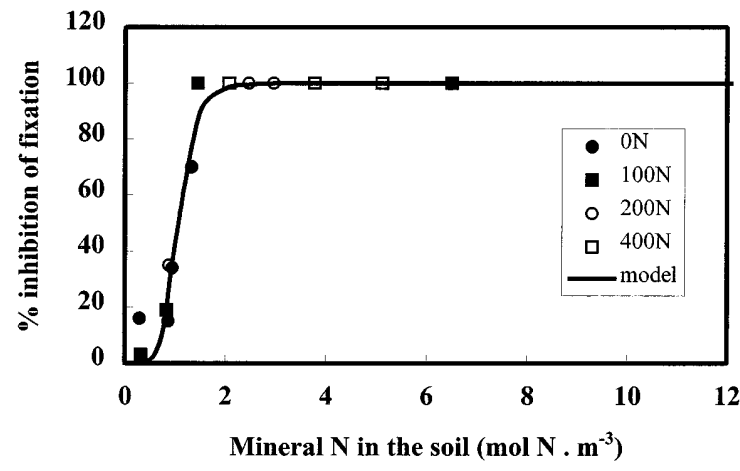

Figure 9. Inhibition of symbiotic $\mathrm{N}$ fixation by mineral $\mathrm{N}$ availability in the soil. The symbols correspond to treatments of pea, cv. Frisson with various doses of mineral $\mathrm{N}$ added as fertiliser at sowing (from [75]).

tioning at the plant level and the soil environment, the level of mineral $\mathrm{N}$ availability and its effect on root and nodule morphogenesis and $\mathrm{N}$ retrieval activities during the crop growth cycle.

Knowing the regulatory processes responsible for adaptive responses of the root system is essential for enhancing the $\mathrm{N}$ balance in the field and for creating and evaluating genotypes with a better efficiency of $\mathrm{N}$ retrieval. The objectives are to provide guidance for selection of a type of plant whose characteristics would allow root mineral $\mathrm{N}$ assimilation to compensate for declines in symbiotic $\mathrm{N}_{2}$ fixation during seed filling when nodule functioning is greatly reduced because of water stress or $\mathrm{N}$ feedback.

\section{REFERENCES}

[1] Amarger N., Mariotti A., Mariotti F., Essai d'estimation du taux d'azote fixé symbiotiquement chez le lupin par le traçage isotopique naturel, C. R. Acad. Sci. 284 (1977) 2179-2182.

[2] Amarger N., Mariotti A., Mariotti F., Durr J.C., Bourguignon C., Lagacherie B., Estimate of symbiotically fixed nitrogen in field grown soybean using variations in ${ }^{15} \mathrm{~N}$ natural abundance, Plant and Soil 52 (1979) 269-280.

[3] Armstrong E.L., Pate J.S., Unkovich M.J., Nitrogen balance of field pea crops in South Western Australia, studied using the ${ }^{15} \mathrm{~N}$ natural abundance technique, Aust. J. Plant Physiol. 21 (1994) 533-549.

[4] Askin D.C., White J.G.H., Rhodes P.J., Nitrogen fixation by peas and their effect on soil fertility, in: Hebblethwaite P.H., Heath M., Dawkins T.C.K. (Eds.), The pea crop, Butterworths, London, 1985, pp. 421-430. 
[5] Atta S., Étude de la variabilité génétique pour la fixation et la remobilisation de l'azote chez le pois (Pisum sativum L.). incidence sur la teneur en protéines des grains, Thèse, Université de Rennes I, 135 p.

[6] Atkins C.A., Herridge D.F., Pate J.S., Isotopes in biological dinitrogen fixation, International Atomic Agency, Vienna, 1978, pp. 211-242.

[7] Beck D.P., Wery J., Saxena M.C., Ayadi A., Dinitrogen fixation and nitrogen balance in cool-season food legumes, Agron. J. 83 (1991) 334-341.

[8] Bergersen F.J., Turner G.L., Peoples M.B., Gault R.R., Morthorpe L.J., Brockwell J., Nitrogen fixation during vegetative and reproductive growth of irrigated soybeans in the field: application of ${ }^{15} \mathrm{~N}$ methods, Aust. J. Agric. Res. 43 (1992) 145-153.

[9] Brouquisse R., Fischer A., Raymond P., La protéolyse chez les plantes supérieures : nature, fonction et régulation, in: Morot-Gaudry J.F. (Ed.), Assimilation de l'azote chez les plantes. Aspects physiologique, biochimique et moléculaire, INRA, 1997, pp. 327-350.

[10] Burias N., Planchon C., Paul M.H., Phenotypic and genotypic distribution of nodules on soybean root system inoculated with Bradyrhizobium japonicum strain G49, Agronomie 10 (1990) 57-62.

[11] Caloin M., Yu O., Analysis of the time course of change in nitrogen content in Dactylis glomerata L. using a model of plant growth, Ann. Bot. 54 (1984) 69-76.

[12] Cousin R., Peas (Pisum sativum L.), Field Crops Res. 53 (1997) 111-130.

[13] Curioni P.M.G., Hartwig U.A., Nosberger J., Schuller K.A., Glycolitic flux is adjusted to nitrogenase activity in nodules of detopped and argon-treated alfalfa plants, Plant Physiol. 119 (1999) 445-453.

[14] Denison R.F, Harter B.L., Nitrate effect on nodule permeability and leghemoglobin, Plant Physiol. 107 (1995) 1355-1364.

[15] Drevon J.J., Hartwig U.A., Phosphorus deficiency increases the argon-induced decline of nodule nitrogenase activity in soybean and alfalfa, Planta 201 (1997) 463-469.

[16] Duc G., Mariotti A., Amarger N., Measurements of genetic variability for symbiotic dinitrogen fixation in fieldgrown faba bean (Vicia faba L.) using a low level ${ }^{15} \mathrm{~N}$-tracer technique, Plant and Soil 106 (1988) 269-276.

[17] Duc G., Messager A., Mutagenesis of pea (Pisum sativum L.) and the isolation of mutants for nodulation and nitrogen fixation, Plant Sci. 60 (1989) 207-213.

[18] Faurie O., Soussana J.F., Oxygen induced recovery from short-term nitrate inhibition of $\mathrm{N}_{2}$ fixation in white clover plants from spaced and dense strands, Physiol. Plant 88 (1993) 467-475.

[19] Garcia R.L., Hanway J.J., Foliar fertilization of soybeans during the seed-filling period, Agron. J. 68 (1976) 653-657.

[20] Glick B.R., The enhancement of plant growth by freeliving bacteria, Can. J. Microbiol. 41 (1995) 109-117.
[21] Grandgirard D., Munier-Jolain N., Salon C., Ney, B., Nitrogen nutrition level and temperature effects on vegetative $\mathrm{N}$ remobilisation rate and distribution of canopy $\mathrm{N}$ during seed filling period in soybean (Glycine max L. Merr.), Proceedings of the 4th European Conference on Grain Legumes, Cracow, Poland (2001) 30-31.

[22] Groppa M.D., Zawoznik M.S. Tomaro M.L., Effect of co-inoculation with Bradyrhizobium japonicum and Azospirillum brasilense on soybean plants, Eur. J. Soil Biol. 34 (1998) 75-80.

[23] Hamblin A.P., Hamblin J., Root characteristics of some legume species and varieties on deep, free-draining entisols, Aust. J. Agric. Res. 36 (1985) 63-72.

[24] Harding S.C., Sheehy J.E., Influence of shoot and root temperature on leaf growth, photosynthesis and nitrogen fixation of lucerne, Ann. Bot. 45 (1980) 229-233.

[25] Harper J.E., Cooper R.L., Nodulation response of soybeans (Glycine max L. Merr.) to application rate and placement of combined nitrogen, Crop Sci. 11 (1971) 438-440.

[26] Hartwig U.A., The regulation of symbiotic $\mathrm{N}_{2}$ fixation: a conceptual model of $\mathrm{N}$ feedback from the ecosystem to the gene expression level. Perspectives in Plant Ecology, Evol. Syst. 1 (1998) 92-120.

[27] Hatfield P.M., Vierstra R.D., Protein degradation, in: D.D.T. Turpin D.H., Lefebvre D.D., Layzell D.B. (Eds.), Plant metabolism, Longman, 1997, pp. 26-36.

[28] Hocking P.J., Pate J.S., Accumulation and distribution of mineral elements in annual lupins Lupinus albus L. and Lupinus angustifolius L., Aust. J. Agric. Res. 29 (1978) 267-280.

[29] Holl F.B., Vose J.R., Carbohydrate and protein accumulation in the developing field pea seed, Can. J. Plant Sci. 60 (1980) 1109-1114.

[30] Jacobsen E., Feenstra W.J., A new pea mutant with efficient nodulation in the presence of nitrate, Plant Sci. Lett. 33 (1984) 337-344.

[31] Jensen E.S., The influence of rate and time of nitrate supply on nitrogen fixation and yield in pea (Pisum sativum L.), Fertil. Res. 10 (1986) 193-202.

[32] Jensen E.S., Seasonal patterns of growth and nitrogen fixation in field-grown pea, Plant and Soil 101 (1987) 29-37.

[33] Jeuffroy M.H., Warembourg F.R., Carbon transfer and partitioning between vegetative and reproductive organs in Pisum sativum L., Plant Physiol. 97 (1991) 440-448.

[34] Kouchi H., Akao S., Yoneyama T., Respiratory utilization of ${ }^{13} \mathrm{C}$-Labelled photosynthetate in nodulated root systems of soybean plants, J. Exp. Bot. 37 (1986) 989-993.

[35] Lawrie A.C., Wheeler C.T., The effects of flowering and fruit formation on the supply of photosynthetic assimilates to the nodules of Pisum sativum L. in relation to the fixation of nitrogen, New Phytol. 60 (1974) 817-821.

[36] Lemaire G., Salette J., Relation entre dynamique de croissance et dynamique de prélèvement d'azote pour un peuplement de graminées fourragères. II. Étude de la variabilité entre génotypes, Agronomie 4 (1984) 431-436. 
[37] Lhuillier-Soundélé A., Analyse de l'élaboration de la teneur en azote des graines chez le pois (Pisum sativum L.). Modélisation de la répartition de l'azote vers les graines en remplissage, Thèse doc. INA-PG, 1999.

[38] Lhuillier-Soundele A., Munier-Jolain N.G., Ney B., Dependence of seed nitrogen concentration on plant $\mathrm{N}$ availability during the seed filling in pea, Eur. J. Agron. 11 (1999) 157-166.

[39] Lhuillier-Soundele A., Munier-Jolain N.G., Ney B., Influence of nitrogen availability on seed nitrogen accumulation in pea, Crop Sci. 39 (1999) 1741-1748.

[40] Mariotti A., Mariotti F., Amarger N., Fractionnements isotopiques de l'azote lors des processus d'absorption des nitrates et de fixation de l'azote atmosphérique par les plantes, Physiol. Vég. 18 (1980) 163-181.

[41] Mariotti A., Mariotti F., Amarger N., Utilisation du traçage isotopique naturel par ${ }^{15} \mathrm{~N}$ pour la mesure du taux d'azote fixé symbiotiquement par les légumineuses, Physiol. Vég. 21 (1983) 279-291.

[42] Munier-Jolain N.G., Ney B., Duthion C., Termination of seed growth in relation to nitrogen content of vegetative parts in soybean plants, Eur. J. Agron. 5 (1996) 219-225.

[43] Munier-Jolain N., Boutin J.P., Planchot V., Colonna P., Salon C., Duc G., Buleon A., Lhuillier-Soundele A., Page D., Quillien L., Rochat C., Roux Y., Wuillème S., Élaboration de la qualité des graines de pois : influences environnementales sur leur qualité nutritionnelle et leur valeur technologique, in: Albagnac G., Colonna P., Doussinault G., Habib R. (Eds.), AIP-AGRAF pour l'élaboration de la composition et de l'aptitude à l'utilisation des graines et des fruits 1996-1999, INRA, 2000, pp. 43-66.

[44] Murphy P.M., Effect of light and atmospheric carbon dioxide concentration on nitrogen fixation by herbage legumes, Plant and Soil 95 (1986) 399-409.

[45] Neo H.H., Layzell D.B., Phloem glutamine and the regulation of $\mathrm{O}_{2}$ diffusion in legume nodules, Plant Physiol. 113 (1997) 259-267.

[46] Newcomb W., A correlated light and electron microscopic study of symbiotic growth and differenciation in Pisum sativum root nodules, Can. J. Bot. 54 (1976) 2163-2186.

[47] Ney B., Doré T., Sagan M., Grain legumes, in: Lemaire G. (Ed.), Diagnosis of the nitrogen status in crops, SpringerVerlag, Berlin, 1997, pp. 107-117.

[48] Okon Y., Vanderleyden J., Root-associated Azospirillum species can stimulate plants, ASM News 63 (1997) 366-370.

[49] Parsons R., Stanforth A., Raven A.J., Sprent J.I., Nodule growth and activity may be regulated by a feedback mechanism involving phloem nitrogen, Plant Cell Environ. 16 (1993) 125-136.

[50] Pate J.S., Flinn A.M., Fruit and seed development, in: Sutcliffe J.F., Pate J.S. (Eds.), The physiology of garden pea, Academic press, New York, 1977, pp. 431-468.

[51] Pate J.S., Physiology of pea - a comparison with other legumes in terms of economy of carbon and nitrogen in wholeplant and organ functioning, in: Hebblewaite P.D., Heath M.C.,
Dawkins T.C.K. (Eds.), The pea crop. Butterworths, London, 1985, pp. 279-296.

[52] Pederson G.A., Taproot and adventitious root growth of white clover as influenced by nitrogen nutrition, Crop Sci. 29 (1989) 764-768.

[53] Peoples M.B., Dalling M.J., Proteolysis and amino acid metabolism, in: Nooden L.D., Leopold A.C. (Eds.), Senescence and aging in plants, Academic press, New York, 1988, pp. 182-217.

[54] Rennie R.J., Rennie D.A., Techniques for quantifying $\mathrm{N}_{2}$ fixation in association with nonlegumes under field and greenhouse conditions, Can. J. Microbiol. 29 (1983) 1022-1035.

[55] Richards J.E., Soper R.J., Effect of N-fertilizer on yield, protein content, and symbiotic $\mathrm{N}$ fixation in faba beans, Agron. J. 71 (1979) 807-811.

[56] Rodelas B., González-López J., Salmerón V., Pozo C., Martínez-Toledo M., Enhancement of nodulation, $\mathrm{N}_{2}$ fixation and growth of faba bean (Vicia faba L.) by combined inoculation with Rhizobium leguminosarum bv. Viceae and Azospirillum brasilense, Symbiosis 21 (1996) 175-186.

[57] Rodríguez H., Fraga R., Phosphate solubilizing bacteria and their role in plant growth promotion, Biotechnol. Adv. 17 (1999) 319-339.

[58] Sagan M., Duc G., Sym 28 and Sym29, two new genes involved in regulation of nodulation in Pea (Pisum sativum L.), Symbiosis 20 (1996) 229-245.

[59] Sagan M., Gresshoff P.M., Developmental mapping of nodulation events in pea (Pisum sativum L.) using supernodulating plant genotypes and bacterial variability reveals both plant and Rhizobium control of nodulation regulation, Plant Sci. 117 (1996) 167-179.

[60] Sagan M., Ney B., Duc G., Plant symbiotic mutants as a tool to analyse nitrogen nutrition and yield relationship in field-grown peas (Pisum sativum L.), Plant and Soil 153 (1993) $33-45$.

[61] SAS institute. SAS/STAT Guide for Personal Computer, 6th edition, SAS institute, Cary, 1987, NC.

[62] Salon C., Munier-Jolain N.G., Ney B., Duthion C., Use of the ${ }^{15} \mathrm{~N}$ isotope dilution technique on short time interval for the determination of the percentage of $\mathrm{N}$ derived from symbiotic fixation by pea (Pisum sativum L.) during the growth cycle, Proceedings of the 3rd European Conference on Grain Legumes, Valladolid, Spain, 1998, 408.

[63] Salon C., Voisin A.S., Mary B., Measurement of symbiotic nitrogen fixation in the field using a multi-enrichment technique, Proceedings of the 4th European Conference on Grain Legumes, Cracow, Poland (2001) 330-331.

[64] Sanetra C.M., Ito O., Virmani S.M., Vlek P.L.G., Remobilization of nitrogen from senescing leaves of pigeonpea (Cajanus cajan (L.) Millsp.): genotypic differences across maturity groups?, J. Exp. Bot. 49 (1998) 853-862.

[65] Serraj R., Sinclair T.R., Purcell L.C., Symbiotic $\mathrm{N}_{2}$ fixation response to drought, J. Exp. Bot. 50 (1999) 143-155.

[66] Serraj R., Fleurat-Lessart P., Jaillard B., Drevon J.J., Structural changes in the inner-cortex cells of soybean root 
nodules are induced by short-term exposure to high salt or oxygen concentrations, Plant Cell Environ. 18 (1995) 455-462.

[67] Serraj R., Vadez V., Denison R.F., Sinclair T.R., Involvement of ureides in nitrogen fixation inhibition in soybean, Plant Physiol. 119 (1999) 289-296.

[68] Sinclair T.R., de Wit C.T., Analysis of the carbon and nitrogen limitations to soybean yield, Agron. J. 68 (1976) 319-324.

[69] Sparrow S.D., Cochran V.L., Sparrow E.B., Dinitrogen fixation by seven legume crops in Alaska, Agron. J. 87 (1995) 34-41.

[70] Sprent J.I., Stephens J.H., Rupela O.P., Environmental effects on nitrogen fixation, in: Summerfield R.J. (Ed.), World crops: cool season food legumes, Kluwer Academic Publishers, 1988, pp. 801-810.

[71] Streeter J.G., Effect of N starvation of soybean plants at various stages of growth on seed yield and $\mathrm{N}$ concentration of plant parts at maturity, Agron. J. 70 (1978) 74-76.

[72] Thorup-Kristensen K., Root growth of green pea (Pisum sativum L.) genotypes, Crop Sci. 38 (1998) 1445-1451.

[73] Tricot F., Crozat Y., Pellerin S., Root system growth and nodule establishment on pea (Pisum sativum L.), J. Exp. Bot. 48 (1997) 1935-1941.

[74] Vessey J.K., Cultivar differences in assimilate partitioning and capacity to maintain $\mathrm{N}_{2}$ fixation rate in pea during pod-filling, Plant and Soil 139 (1992) 185-194.

[75] Voisin A.S., Emery R.N., Munier-Jolain N.M., Ney B., Salon C., Relationship between the activity of nitrogen fixation and soil nitrogen availability throughout the growth cycle of pea, Proceedings of the Mediterranean Conference of Rhizobiology, Fabamed, Montpellier, 9-13th September, 2000.

[76] Voisin A.S., Munier-Jolain N., Ney B., Salon C., Influence of soil nitrate availability on symbiotic $\mathrm{N}_{2}$ fixation, nitrogen nutrition and biomass partitioning between shoot and root of pea, Proceedings of the 4th European Conference on Grain Legumes, Cracow, Poland (2001) 29.
[77] Wery J., Relations entre la nutrition azotée et la production chez les légumineuses, in: Guy P. (Ed.), Nutrition azotée des Légumineuses, Les colloques de L'INRA, n 37 , Paris (1987) 199-224.

[78] Witty J.F., Roughley R.J., Day J.M., Reduction of yield of Vicia faba by foliar fertilization during the seed-filling period, J. Agric. Sci. Camb. 94 (1980) 741-743.

[79] Wu S., Harper J.E., Dinitrogen fixation potential and yield of hypernodulating soybean mutants: a field evaluation, Crop Sci. 31 (1991) 1233-1240.

[80] Yoneyama T., Ishizuka J., ${ }^{15} \mathrm{~N}$ study on the partitioning of the nitrogen taken by soybeans from atmospheric dinitrogen, medium nitrate or ammonium, Soil Sci. Plant Nutr. 28 (1982) 451-461.

[81] Warembourg F.R., Estimating the cost of dinitrogen fixation by nodulated plants in undisturbed conditions, Can. J. Microbiol. 29 (1983) 930-937.

[82] Warembourg F.R., Haegel B., Fernandez M.P., Montange D., Distribution and utilization of assimilated carbon in relation to dinitrogen fixation in soybean, Plant and Soil 82 (1984) 163-178.

[83] Warembourg F.R., Fernandez M.P., Distribution and remobilization of symbiotically fixed nitrogen in soybean (Glycine max), Physiol. Plant. 65 (1985) 281-286.

[84] Warembourg F.R., Roumet C., Why and how to estimate the cost of symbiotic $\mathrm{N}_{2}$ fixation? A progressive approach based on the use of ${ }^{14} \mathrm{C}$ and ${ }^{15} \mathrm{~N}$ isotopes, Plant and Soil 115 (1989) 167-177.

[85] Walsh K.B., Vessey K.J., Layzell D.B., Carbohydrate supply and $\mathrm{N}_{2}$ fixation in soybean. The effect of varied daylength and stem girdling, Plant Physiol. 85 (1987) 137-144.

[86] Zahran H.H., Sprent J.I., Effects of sodium chloride and polyethylene glycol on root hair infection and nodulation of Vicia faba L. plants by Rhizobium leguminosarum, Planta 167 (1986) 303-309.

To access this journal online: www.edpsciences.org 